\title{
PERENCANAAN PRODUKSI \\ MENGGUNAKAN GOAL PROGRAMMING \\ (Studi Kasus di Bakpia Pathuk 75 Yogyakarta)
}

\author{
Laila Nafisah, Sutrisno, Yan Ellia H. Hutagaol \\ Program Studi Teknik Industri Fakultas Teknologi Industri \\ Universitas pembangunan Nasional "Veteran" Yogyakarta \\ lailanafisah71@gmail.com
}

\begin{abstract}
Abstrak
Semakin berkembangnya jumlah UKM yang memproduksi bakpia di Yogyakarta maka membuat persaingan semakin meningkat. Sehingga setiap owner selain harus memiliki inovasi dalam produksi dan pemasaran, mereka juga harus memiliki perencanaan produksi yang baik untuk mempertahankan stabilitas keuangan perusahaan. Bakpia Patuk 75 adalah perusahaan yang memproduksi bakpia dengan berbagai macam varian rasa.Setiap jenis varian yang dijual memiliki harga pokok produksi dan tingkat permintaan yang berbeda. Namun demikian perencanaan produksi yang dijalankan perusahaan kadangkala tidak dapat memenuhi permintaan pembeli yang berfluktuasi. Akibatnya seringkali terjadi kelebihan dan kekurangan produk. Perusahaan berkeinginan meminimalkan biaya produksi dan sekaligus memaksimalkan sumberdaya yang dimilikinya.dimana kedua tujuan tersebut memiliki sifat yang saling bertentangan satu sama lain dalam upaya pencapainnya. Untuk membantu memecahkan permasalahan multi objektif tersebut digunakan pendekatan goal programming. Hasil perencanaan produksi dengan menggunakan metode Goal Programming ini mampu menghasilkan kombinasi produk yang dapat dijadikan dasar untuk menentukan jumlah produk yang akan diproduksi berdasarkan sasaran-sasaran yang diinginkan perusahaan.
\end{abstract}

Kata kunci : Perencanaan Produksi, Multiple Criteria Decision Making,Goal Programming.

\section{PENDAHULUAN}

Yogyakarta adalah salah satu objek wisata yang menjadi perhatian oleh turis lokal maupun mancanegara. Selain tempat wisata alam, bakpia merupakan kuliner wisata khas daerah yang sangat dicari oleh turis jika sedang berkunjung ke Yogyakarta. Berkembangnya UKM yang memproduksi bakpia membuat persaingan semakin meningkat. Hal ini membuat setiap owner selain harus memiliki inovasi dalam pemasaran dan produksi, mereka juga harus memiliki perencanaan produksi yang baik untuk mempertahankan stabilitas keuangan perusahaan. Karena perencanaan dan pengendalian produksi merupakan usaha-usaha manajemen untuk merencanakan dasar-dasar daripada proses produksi dan aliran bahan, sehingga menghasilkan produk yang dibutuhkan pada waktunya dengan biaya yang seminimum mungkin dan mengatur serta menganalisa mengenai pengorganisasian dan pengkoordinasian bahan-bahan, mesin-mesin dan peralatan, tenaga manusia dan tindakantindakan lain yang dibutuhkan (Nasution dan Prasetyawan, 2008).

Bakpia Patuk 75 adalah perusahaan yang memproduksi bakpia dan telah berdiri sejak 1948.Sampai saat ini Bakpia Patuk 75 masih menjadi salah satu produsen bakpia yang enak dan terkenal di Indonesia sehingga dapat berkembang dan bertahan sampai saat ini.Saat ini Bakpia Patuk 75 memiliki 2 pabrik dengan mempekerjakan sejumlah 88 karyawan dengan tugas yang berbeda.Berbagai macam varian rasa telah dibuat seperti rasa keju, coklat, kacang hijau, kumbu hitam, durian, nanas, strawberry, coklat krispi, dan bakpia Tugu yang dapat bertahan selama sebulan.Namun tetap produk utamanya adalah bakpia dengan rasa keju, coklat, kumbu hitam, kacang hijau dan coklat krispi, dan bakpia Tugu.

Setiap jenis varian yang dijual memiliki harga pokok produksi dan tingkat permintaan akan masing-masing jenis produk yang berbeda. Ketika permintaan meningkat, pihak manajemen mengambil kebijakan bahwa Bakpia Patuk 75 harus meningkatkan output produksinya sesuai perkiraan. Pihak manajemen tentunya menginginkan bahwa jumlah bakpia yang diproduksi dapat memenuhi seluruh permintaan sehingga pendapatan 
perusahaan meningkat. Dengan kapasitas sumber daya seperti mesin, jam kerja dan tenaga kerja yang terbatas, manajemen mengambil keputusan untuk melakukan penambahan kapasitas yang tersedia. Salah satu keputusan yang diambil oleh pihak manajemen adalah dengan merekrut karyawan tidak tetap atau memberlakukan lembur, bahkan tidak jarang keduanya dilakukan jika memang keadaan mengharuskan. Penambahan pegawai dan memberlakukan waktu lembur tentunya membuat biaya produksi semakin bertambah. Namun tidak dipungkiri bahwa manajemen menginginkan biaya produksi yang seminimum mungkin sehingga keuntungan perusahaan semakin bertambah. Dan keuntungan tersebut bisa digunakan untuk dialokasikan menambah investasi lain atau mengembangkan lebih luas bisnis bakpia yang sudah ada sekarang.

Dapat dilihat bahwa ada 2 tujuan yaitu Bakpia Patuk 75 minimal ingin memenuhi semua permintaan dengan meminimasi biaya produksi, dan menggunakan kapasitas yang tersedia dengan optimal. Dengan kondisi ini maka Goal Programming dapat diterapkan untuk memberi solusi bagi manajemen. Dimana Goal Programming merupakan salah satu metode yang biasa digunakan untuk mencari solusi dengan fungsi tujuan lebih dari satu (multi objective) dimana tujuan tersebut saling bertentangan satu sama lain. Pada Goal Programming terdapat bobot penalti sebagai "hukuman" akibat tidak mencapai target yang telah ditetapkan. Dan juga deviasi yang merupakan nilai penyimpangan antara hasil perhitungan dan target/sasaran perusahaan.

\section{LANDASAN TEORI}

\section{A. Perencanaan Produksi}

Menurut Nasution dan Prasetyawan (2008), perencanaan produksi dilakukan dengan tujuan menentukan arah awal dari tindakan-tindakan yang harus dilakukan dimasa mendatang, apa yang harus dilakukan, berapa banyak melakukannya, dan kapan harus melakukan. Karena perencanaan ini berkaitan dengan masa mendatang, maka perencanaan disusun atas dasar perkiraan yang dibuat berdasarkan data masa lalu dengan menggunakan beberapa asumsi.

Tujuan perencanaan produksi adalah (Ginting, 2007):

a) Sebagai langkah awal untuk menentukan aktivitas produksi yaitu sebagai referensi perencanaan lebih rinci dari rencana agregat menjadi item dalam jadwal induk produksi.

b) Sebagai masukan rencana sumber daya sehingga perencanaan sumber daya dapat dikembangkan untuk mendukung perencanaan produksi.

c) Meredam (stabilisasi) produksi dan tenaga kerja terhadap fluktuasi permintaan.

Pada dasarnya fungsi dasar yang harus dipenuhi oleh aktivitas perencanaan dan pengendalian produksi (Kusuma, 2009):

a. Meramalkan permintaan produk

b. Menetapkan jumlah dan saat pemesanan bahan baku secara ekonomis dan terpadu.

b) Menetapkan keseimbangan antara tingkat kebutuhan produksi, teknik pemenuhan pesanan, serta memonitor tingkat persediaan produk jadi setiap saat, membandingkannya dengan rencana persediaan dan melakukan revisi atas rencana produksi pada saat yang ditentukan.

c) Membuat jadwal produksi, penugasan, pembebanan measin dan tenaga kerja yang terperinci sesuai dengan ketersediaan kapasitas dan fluktuasi permintaan pada suatu periode.

\section{B. Goal Programming}

Goal Programming (GP) adalah metode yang membutuhkan informasi ordinal dan kardinal untuk pengambilan keputusan multi tujuan (Tabucanon, 1988). Pada GP, variabel deviasi (dari tujuan-tujuan) dengan tugas prioritas dan bobot adalah di minimasi dibandingkan mengoptimalkan tujuan kriteria secara langsung seperti pada 
Linear Programming (LP). Asumsi pada LP seperti additivity, homogeneity, dan linearity harus ditemukan juga pada GP, kecuali unidimensionality. Sifat dasar dari model LP di ekspresikan pada istilah satu kriteria yang terukur. Sebenarnya asumsi ini jarang terpenuhi.GP menyediakan kesempatan untuk mengatasi masalah dengan multi tujuan yang mungkin tidak dapat dibandingkan.Sangat sering, tujuan-tujuan tersebut multidimensi tetapi juga bertentangan.GP mengijinkan tujuan-tujuan (goals) yang ditetapkan dan tetap menghasilkan solusi yang dapat diterima. Pada LP, semua kendala (constraints) yang diberikan sama pentingnya dan harus terpenuhi semuanya, sementara GP mengolah tujuan manajerial dan kendala sebagai tujuan dengan prioritas yang berhubungan.

Menurut Britania (2011) Linear goal programming (LGP) adalah pengembangan dari linear programming (LP) dimana terdapat beberapa fungsi tujuan yang ingin dicapai, sebagai contoh, sebuah perusahaan memiliki tujuan memaksimalkan keuntungan dan meminimalkan pengeluaran. Hal ini tidak dapat dilakukan dengan LP karena pada LP hanya terdapat satu fungsi tujuan.Linear Programming adalah salah satu model dalam menyelesaikan riset operasi. Riset operasi dapat didefinisikan sebagai model matematis yang digunakan untuk menentukan solusi optimal pada suatu permasalahan dengan kondisi sumber daya yang terbatas, sehingga dapat dikatakan bahwa riset operasi termasuk metode untuk optimasi.

Goal Programming disebut juga dengan pemrograman sasaran. Goal programming berkaitan dengan masalah pemrograman yang mencakup dua tujuan atau lebih.Pendekatan dasarnya adalah menetapkan satu sasaran numerik tertentu dari tiap tujuan, merumuskan suatu fungsi tujuan dari tiap-tiap tujuan dan mencari solusi yang meminimasi jumah deviasi dari fungsi tujuan ini dengan sasarannya masing-masing. Kasus dalam goal programming dibagi menjadi dua, yaitu (Indrianti et al, 2015):

a) Nonpreemptive goal programming, dimana semua sasaran dapat dibandingkan tingkat kepentingannya melalui bobot.

b) Preemptive goal programming, dimana tingkat kepentingan sasaran dinyatakan dengan prioritas.

\section{Nonpreemptive Goal Programming}

Model matematika dari permasalahan nonpreemptive goal programming adalah

Minimasi

$$
\begin{aligned}
& z=\sum_{i=1}^{m}\left(w_{i}^{+}+w_{i}^{-} d_{i}^{-}\right) \ldots \ldots \ldots \ldots \\
& \sum_{j=1}^{n} a_{i j} x_{j}+\left(d_{i}^{+}-d_{i}^{-}\right)=b_{i}, \forall_{i} \\
& x_{j}, d_{i}^{+}, d_{i}^{-} \geq 0, \forall(i, j)
\end{aligned}
$$

Dengan:

$x_{j} \quad$ : variabel keputusan ke $\mathrm{j}$

$d_{i}^{+} \quad$ : variabel pembantu yang menyatakan adanya penyimpangan suatu tujuan di atas sasarannya.

$d_{i}^{-} \quad$ : variabel pembantu yang menyatakan adanya penyimpangan suatu tujuan di bawah sasarannya.

$w_{i}^{+} \quad$ : bobot penalti karena terjadinya penyimpangan suatu tujuan di atas sasaran.

$w_{i}^{-} \quad$ : bobot penalti karena terjadinya penyimpangan suatu tujuan di bawah sasaran.

$a_{i j} \quad$ : koefisien yang menyatakan sumbangan terhadap tujuan ke i pada variabel keputusan ke j

\section{METODOLOGI PENELITIAN}

Data yang dibutuhkan dalam penelitian ini adalahdiagram alir proses produksi, data waktu proses produksi, data penjualan produk 1 tahun terakhir, data ketersediaan jam kerja, data biaya tenaga kerja, data biaya lembur, data tenaga kerja kontrak, data biaya bahan baku, data biaya overhead pabrik, harga jual produk dan data produksi maksimum masingmasing produk.Adapun alur penelitian yang dilakukan dapat dilihat pada Gambar 1. 


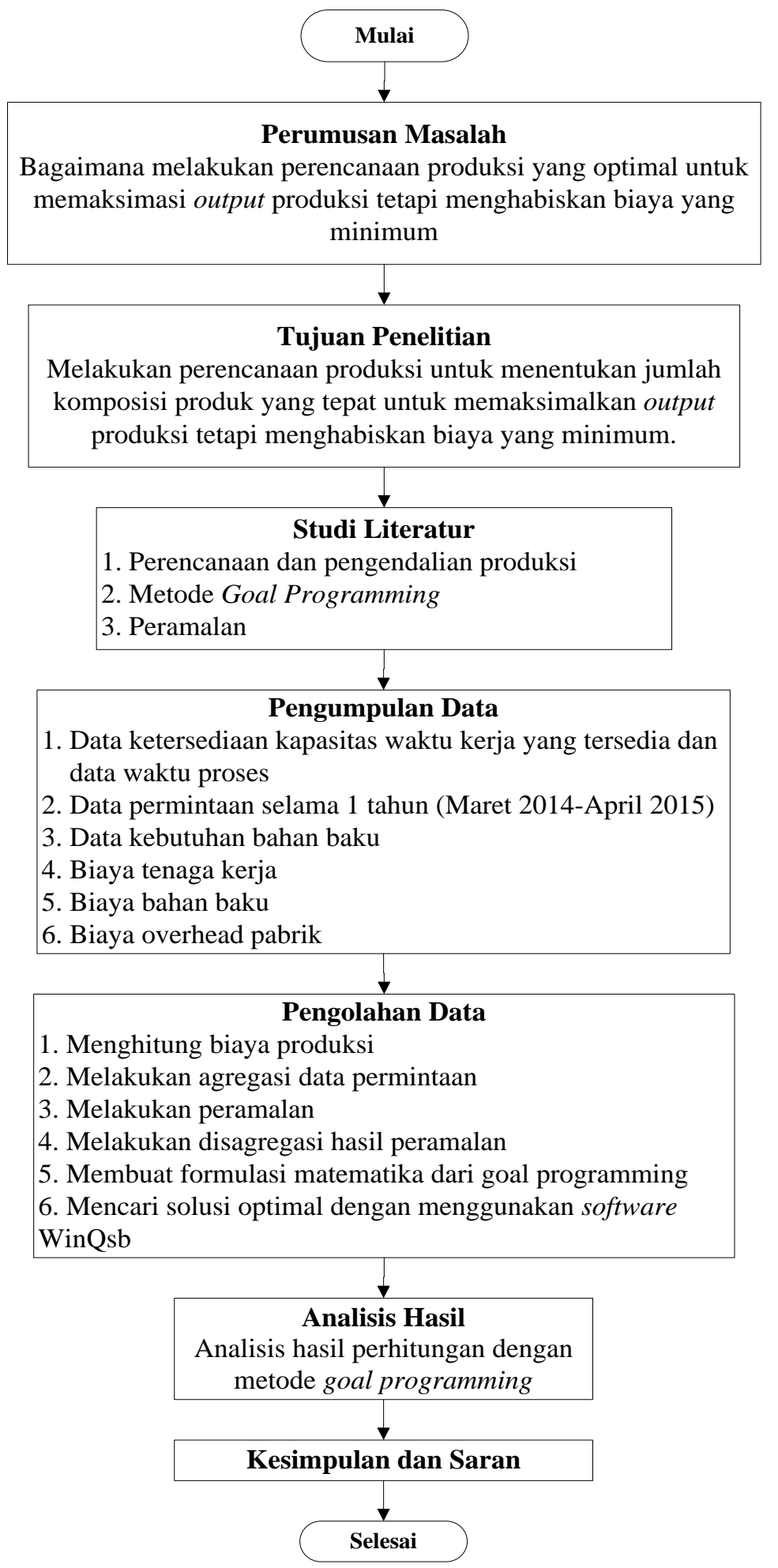

Gambar 1. Diagram alir penelitian 


\section{HASIL DAN PEMBAHASAN}

Data-data yang dikumpulkan dapat dilihat pada tabel-tabel dibawah ini

Tabel 1. Kapasitas mesin yang tersedia per hari

\begin{tabular}{|c|l|c|c|}
\hline No. & \multicolumn{1}{|c|}{ Mesin } & Jumlah & Kapasitas Tersedia (menit) \\
\hline 1. & Kompor kukus & 2 & 960 \\
\hline 2. & Drum Besar & 4 & 1920 \\
\hline 3. & Mesin Giling & 2 & 960 \\
\hline 4. & Mesin Masak Bumbu & 9 & 4320 \\
\hline 5. & Mesin Membuat Kulit Bakpia & 2 & 960 \\
\hline 6. & Oven Tungku & 8 & 3840 \\
\hline 7. & Oven Listrik & 2 & 960 \\
\hline 8. & Mesin Perata Adonan Kulit & 1 & 480 \\
\hline \multicolumn{2}{|c|}{ Total Waktu } & 14400 \\
\hline
\end{tabular}

Tabel 2. Total biaya produksi, $\mathrm{Rp}$ per unit

\begin{tabular}{|c|l|c|c|c|c|c|c|}
\hline No. & \multicolumn{1}{|c|}{ Produk } & $\begin{array}{c}\text { Biaya } \\
\text { Bahan } \\
\text { Baku }\end{array}$ & $\begin{array}{c}\text { Biaya } \\
\text { Tenaga } \\
\text { Kerja }\end{array}$ & $\begin{array}{c}\text { Biaya } \\
\text { Overhea } \\
\text { d Pabrik }\end{array}$ & $\begin{array}{c}\text { Biaya } \\
\text { Lemb } \\
\text { ur }\end{array}$ & $\begin{array}{c}\text { Biaya } \\
\text { Kontrak } \\
\text { Karyaw } \\
\text { an }\end{array}$ & $\begin{array}{c}\text { Total } \\
\text { Biaya } \\
\text { Produks } \\
\text { i }\end{array}$ \\
\hline 1. & $\begin{array}{l}\text { Bakpia Kacang } \\
\text { Hijau }\end{array}$ & 13200 & 1100 & 350 & 3450 & 350 & 18500 \\
\hline 2. & Bakpia Coklat & 19700 & 650 & 600 & 2100 & 350 & 23500 \\
\hline 3. & Bakpia Keju & 16800 & 650 & 600 & 2050 & 350 & 20500 \\
\hline 4. & $\begin{array}{l}\text { Bakpia Kumbu } \\
\text { Hitam }\end{array}$ & 14750 & 1050 & 1200 & 3400 & 350 & 20750 \\
\hline 5. & $\begin{array}{l}\text { Bakpia Coklat } \\
\text { Krispi }\end{array}$ & 19700 & 850 & 4500 & 2700 & 350 & 28150 \\
\hline 6. & $\begin{array}{l}\text { Bakpia Keju } \\
\text { Krispi }\end{array}$ & 16800 & 800 & 4250 & 2600 & 350 & 24800 \\
\hline
\end{tabular}

Tabel 3. Agregasi data permintaan

\begin{tabular}{|c|c|c|c|c|c|c|c|}
\hline Bulan & $\begin{array}{c}\text { Kacang } \\
\text { Hijau }\end{array}$ & Coklat & Keju & $\begin{array}{c}\text { Kumbu } \\
\text { Hitam }\end{array}$ & $\begin{array}{c}\text { Coklat } \\
\text { Krispi }\end{array}$ & $\begin{array}{c}\text { Keju } \\
\text { Krispi }\end{array}$ & Total \\
\hline April & 254275 & 101710 & 76335 & 76230 & 16485 & 17220 & 542255 \\
\hline Mei & 298830 & 49840 & 59780 & 89600 & 16310 & 16975 & 531335 \\
\hline Juni & 331975 & 115990 & 110705 & 103250 & 17080 & 16590 & 695590 \\
\hline Juli & 357455 & 170765 & 144725 & 106365 & 24290 & 24710 & 828310 \\
\hline Agustus & 324135 & 111230 & 106575 & 67795 & 16380 & 16555 & 642670 \\
\hline September & 220010 & 128835 & 112700 & 75145 & 15820 & 16275 & 568785 \\
\hline Oktober & 259980 & 60025 & 79975 & 99995 & 16205 & 16695 & 532875 \\
\hline November & 268625 & 89565 & 79590 & 59710 & 17395 & 17185 & 532070 \\
\hline Desember & 342930 & 164920 & 118755 & 85715 & 24115 & 23555 & 759990 \\
\hline Januari & 271250 & 126175 & 132475 & 100940 & 22470 & 23415 & 676725 \\
\hline Februari & 267435 & 104160 & 118860 & 101010 & 15995 & 17010 & 624470 \\
\hline Maret & 256620 & 105665 & 80710 & 62335 & 16765 & 16625 & 538720 \\
\hline Total & 3453520 & 1328880 & 1221185 & 1028090 & 219310 & 222810 & 7473795 \\
\hline Proporsi & 0,462 & 0,178 & 0,163 & 0,138 & 0,029 & 0,030 & 1 \\
\hline
\end{tabular}


Tabel 4. Disagregasi hasil peramalan

\begin{tabular}{|c|c|c|c|c|c|c|c|c|}
\hline Periode & $\begin{array}{c}\text { Hasil } \\
\text { Peramalan }\end{array}$ & Bulan & $\begin{array}{c}\text { Kacang } \\
\text { Hijau }\end{array}$ & Coklat & Keju & $\begin{array}{c}\text { Kumbu } \\
\text { Hitam }\end{array}$ & $\begin{array}{c}\text { Coklat } \\
\text { Krispi }\end{array}$ & $\begin{array}{c}\text { Keju } \\
\text { Krispi }\end{array}$ \\
\hline April & $609,509,500$ & April & 8047 & 3097 & 2846 & 2396 & 512 & 520 \\
\hline
\end{tabular}

\section{Formulasi Model Matematika Dari Goal Programming}

1. Menentukan fungsi tujuan

Perumusan fungsi tujuan dari Goal Programming dapat dilihat pada persamaan 3.2, maka formulasinya adalah sebagai berikut:

Minimasi $z=1 d_{1}^{+}+35000 d_{2}^{-}+35000 d_{3}^{-}+35000 d_{4}^{-}+35000 d_{5}^{-}+35000 d_{6}^{-}$

2. Menentukan fungsi batasan

$$
+35000 d_{7}^{-}+333,33 d_{8}^{+}+26926,839 d_{8}^{-}
$$

a. Batasan biaya produksi

Meminimasi biaya produksi merupakan salah satu tujuan yang ingin dicapai perusahaan. Fungsi batasan permintaan menggunakan persamaan 3.3, oleh karena itu formulasinya adalah sebagai berikut:

$$
18480,92 X_{1}+23410,14 X_{2}+20438,61 X_{3}+20754,53 X_{4}+28152,50 X_{5}
$$

$$
+24806,04 X_{6}-\left(d_{1}^{+}-d_{1}^{-}\right) \leq 463.532 .371
$$

b. Batasan output produksi

Batasan output produksi memiliki target dengan notasi $D_{i}$ didapat dari hasil peramalan yang dilakukan. Formulasi fungsi pembatas yaitu memaksimasi output produksi:

$$
\begin{aligned}
& X_{1}-\left(d_{2}^{+}-d_{2}^{-}\right) \quad \geq 8047 \\
& \begin{array}{lll}
X_{2} & -\left(d_{3}^{+}-d_{3}^{-}\right) & \geq 3097
\end{array} \\
& \begin{array}{lll}
X_{3} & -\left(d_{4}^{+}-d_{4}^{-}\right) & \geq 2846
\end{array} \\
& \begin{array}{lll}
X_{4} & -\left(d_{5}^{+}-d_{5}^{-}\right) \quad \geq 2396
\end{array} \\
& X_{5} \quad-\left(d_{6}^{+}-d_{6}^{-}\right) \quad \geq 512 \\
& X_{6} \quad-\left(d_{7}^{+}-d_{7}^{-}\right) \geq 520
\end{aligned}
$$

c. Batasan kapasitas yang tersedia

Kapasitas yang tersedia memiliki target jumlah menit yang tersedia dalam pemakaian mesin. Untuk formulasi fungsi batasan kapasitas yang tersedia menggunakan persamaan 3.10, dan dapat dilihat sebagai berikut:

$$
\begin{array}{r}
5,774 X_{1}+1,585 X_{2}+1,756 X_{3}+5,455 X_{4}+2,547 X_{5}+2,571 X_{6} \\
-\left(d_{8}^{+}-d_{8}^{-}\right)=432.000
\end{array}
$$

\section{Formulasi Goal Programming perencanaan untuk bulan April}

Minimasi $\quad z=1 d_{1}^{+}+35000 d_{2}^{-}+35000 d_{3}^{-}+35000 d_{4}^{-}+35000 d_{5}^{-}+35000 d_{6}^{-}+$

Batasan :

$$
35000 d_{7}^{-}+333,33 d_{8}^{+}+26926,839 d_{8}^{-}
$$

$$
\begin{aligned}
& 18480,92 X_{1}+23410,14 X_{2}+20438,61 X_{3}+20754,53 X_{4}+28152,50 X_{5} \\
& +24806,04 X_{6}-\left(d_{1}^{+}-d_{1}^{-}\right) \quad \leq 77.255 .395,22 \\
& X_{1}-\left(d_{2}^{+}-d_{2}^{-}\right) \quad \geq 1342 \\
& X_{2}-\left(d_{3}^{+}-d_{3}^{-}\right) \quad \geq 517 \\
& \begin{array}{lll}
X_{3} & -\left(d_{4}^{+}-d_{4}^{-}\right) \quad \geq 476
\end{array} \\
& \begin{array}{lll}
X_{4} & -\left(d_{5}^{+}-d_{5}^{-}\right) \quad \geq 401
\end{array} \\
& X_{5} \quad-\left(d_{6}^{+}-d_{6}^{-}\right) \quad \geq 87 \\
& X_{6} \quad-\left(d_{7}^{+}-d_{7}^{-}\right) \geq 90 \\
& 5,774 X_{1}+1,585 X_{2}+1,756 X_{3}+5,455 X_{4}+2,547 X_{5}+2,571 X_{6} \\
& -\left(d_{8}^{+}-d_{8}^{-}\right)=72.000 \text {. }
\end{aligned}
$$




\section{KESIMPULAN}

Berdasarkan hasil pengolahan dengan menggunakan metode Goal Programming ini disimpulkan bahwa

1. Terdapat adanya penyimpangan, yang ditunjukkan oleh $d_{1}^{+}$dan $d_{8}^{+}$, yang berarti terjadi penyimpangan diatas sasaran untuk, berturut-turut, fungsi kendala 1 dan fungsi kendala 8, dimana fungsi kendala 1 merepresentasikan tujuan perusahaan yang pertama yaitu meminimasi biaya produksi. Fungsi kendala 8 adalah tujuan perusahaan untuk menggunakan kapasitas mesin sesuai dengan yang tersedia. Nilai $d_{1}^{+}$dan $d_{8}^{+}$ada karena kenaikan nilai hasil perhitungan dari variabel $X_{1}$ yang sangat besar dari sasaran minimal, sehingga mengakibatkan timbulnya nilai deviasi.

2. Hasil perencanaan produksi menghasilkan kombinasi produk yang dapat dijadikan dasar untuk menentukan jumlah produk yang akan diproduksi.

a) Kombinasi jumlah produk yang akan diproduksi pada 5 hari pertama di bulan April adalah 11755 unit rasa kacang hijau, 517 unit rasa coklat, 476 unit rasa keju, 401 unit rasa kumbu hitam, 87 unit rasa coklat krispi dan 90 unit rasa keju krispi.

b) Total biaya produksi yang akan dikeluarkan oleh perusahaan pada bulan April sebesar Rp 84.026.500.

c) Output produksi yang akan dihasilkan perusahaan pada 5 hari pertama di bulan April sebanyak 13.326 unit.

\section{DAFTAR PUSTAKA}

[1] Britania, R. 2011. Penentuan Keputusan Pembelian Bahan Baku Yang Optimal Dengan Metode Analytic Network Process (ANP) dan Goal Programming. Fakultas Teknik. Program Studi Teknik Industri. Universitas Indonesia.

[2] Fogarty, D.W., J.H. Blackstone, and T.R. Hoffman. 1991. Production \& Inventory Management.South-Western Publishing Co. Ohio.

[3] Ginting, R. 2007. Sistem produksi. Graha ilmu. Yogyakarta.

[4] Hendratama, B. 2014. Perencanaan Produksi Dengan Pendekatan Minimum Deviation Method. Jurusan Teknik Industri. Fakultas Teknologi Industri. Universitas Pembangunan Nasional "Veteran" Yogyakarta.

[5] Indrianti, N., dan Sutrisno. Buku Ajar Pengambilan Keputusan Multi Kriteria. 2015. Universitas Pembangunan Nasional "Veteran" Yogyakarta.

[6] Kusuma, H. 2009. Manajemen Produksi. Andi. Yogyakarta.

[7] Makridakis, S., S. C. Wheelwright, dan V. E. McGee. 1995. Metode Dan Aplikasi Peramalan Edisi Kedua. Erlangga. Jakarta.

[8] Nachrowi, N. D., \& H. Usman. 2004. Teknik Pengambilan Keputusan. Grasindo. Jakarta.

[9] Nasution, A. H dan Yudha Prasetyawan. 2008. Perencanaan Dan Pengendalian Produksi. Graha Ilmu. Yogyakarta.

[10] Render, B., dan Jay Heizer. 2001. Prinsip-Prinsip Manajemen Operasi. Salemba Empat. Jakarta.

[11] Sofyan, D. K. 2013. Perencanaan \& Pengendalian Produksi. Graha Ilmu. Yogyakarta.

[12] Tabucanon, M. T. 1988. Multiple Criteria Decision Making In Industri. Elsevier Science Publishing Company, Inc. New York.

[13] Winarno, W. W. 2008. Analisis Manajemen Kuantitatif Dengan WinQSB versi 2.0. UPP STIM YKPN YOGYAKARTA. Yogyakarta. 
